\title{
Study on comparative analysis of tap and stored water quality
}

\section{SWATI SINGH AND AKANKSHA DWIVEDI}

Article Chronicle : Received: 22.01.2016;

Revised :

24.04.2016;

Accepted:

05.05.2016

\begin{abstract}
In the present study the quality of drinking water supplied to the area Mahewa, in Allahabad had been analyzed, through municipal pipe supply and stored water. Following parameters were analyzed to check the water quality. $\mathrm{pH}$ value, hardness, chloride. All the parameters analyzed were according to the Indian standard of drinking water (IS:10500) and were within the permissible limits. The study duration was April to June. Average $\mathrm{pH}$, total hardness, chloride of the tap and stored water ranged from $7.40-8.13$ to $7.32-8.00,40.1-44.9 \mathrm{mg} / \mathrm{lit}$. to $41.1-42.9 \mathrm{mg} / \mathrm{lit} ., 21-24.1 \mathrm{mg} / \mathrm{lit}$. to 22.1-23.1 mg/lit. These tests concluded that the water supplied to the area is fit for the drinking purposes but stored water showed a slight variation in values, which may have resulted due to unhygienic practices in the household. The study also revealed the fact that the water supplied from the pipelines is properly filtered and distributed.

HOW TO CITE THIS ARTICLE : Singh, Swati and Dwivedi, Akanksha (2016). Study on comparative analysis of tap and stored water quality. Asian J. Environ. Sci.,11(1): 45-50, DOI: 10.15740/HAS/AJES/11.1/45-50.
\end{abstract}

Key Words :

Water quality, IS: 10500, pH, Total hardness, Chloride 